\title{
An evaluation of climate, crustal movement and base level controls on the Middle-Late Pleistocene development of the River Severn, UK.
}

\author{
D. Maddy ${ }^{1}$ \\ 1 Department of Geography, University of Newcastle, Daysh Building, Newcastle upon \\ Tyne NE1 7RU. e-mail: darrel.maddy@ncl.ac.uk
}

Manuscript received: April 2001; accepted: February 2002



\begin{abstract}
The Pleistocene development of the lower Severn valley is recorded in the fluvial sediments of the Mathon and Severn Valley Formations and their relationship to the glacigenic Wolston (Oxygen Isotope Stage 12), Ridgacre (OIS 6) and Stockport (OIS 2) Formations. The most complete stratigraphical record is that of the Severn Valley Formation, which post-dates the Anglian Wolston Formation and comprises a flight of river terraces, the highest of which is $\mathrm{c} .50 \mathrm{~m}$ above the present river. The terrace staircase indicates that the Severn has progressively incised its valley during the post-Anglian period. The terrace sediments are predominantly composed of fluvially deposited sands and gravels, largely the result of deposition in high-energy rivers under cold-climate conditions. Occasionally towards the base of these terrace deposits low-energy fluvial facies are preserved which contain faunal remains and yield geochronology which support their correlation with interglacial conditions. This simple stratigraphy supports a climate-driven model for the timing of terrace aggradation and incision, with the incision mode at its most effective during the cold-warm transitions and the aggradational mode at its most effective during warm-cold climate transitions. The chronology of terrace aggradation in the lower Severn seems to correspond with the Milankovitch 100ka climate cycles. The timing of incision events suggests that base level (eustatic sea-level) changes do not play a significant role i.e. incision occurs as sea-level is rising.

Although climate change is significant in governing the timing of incision, the long-term incision of the River Severn appears to be driven by crustal uplift. A long-term incision rate of $0.15 \mathrm{~m} \mathrm{ka}^{-1}$, calculated using the base of the terrace deposits, is believed to closely equate with the long-term uplift rate. Superimposed on this long-term uplift are periods of complex terrace sequence development resulting from rapid incision during periods of glacio-isostatic rebound, with large incision events reflecting the rebound adjustment to late glacial stage isostatic depression. However, in no case in the Severn valley has glacial encroachment led to enhanced incision, suggesting that there has been no additional uplift resulting from isostatic compensation for glacial erosion.
\end{abstract}

Keywords: River Severn, river terraces, uplift rates, glacio-isostatic rebound.

\section{Introduction}

Recently river terrace studies have enjoyed a revival of interest (Bridgland, 2000). Early studies such as that of Penck \& Brückner (1909) used river terrace records to establish evidence for repeated glacial advances. Although such investagations were often prone to over interpretation, more recent research has highlighted the wealth of stratigraphic information that can be de- ciphered from these widespread and important sedimentary archives. This paper discusses one such archive, the sediment/landform assemblages deposited and shaped by the river Severn, UK (Fig. 1). The river Severn has progressively incised its valley during the Quaternary and at least for the latest chapter in this development it has preserved on its present valley sides extensive river terrace deposits that archive a record of changing environmental conditions. 


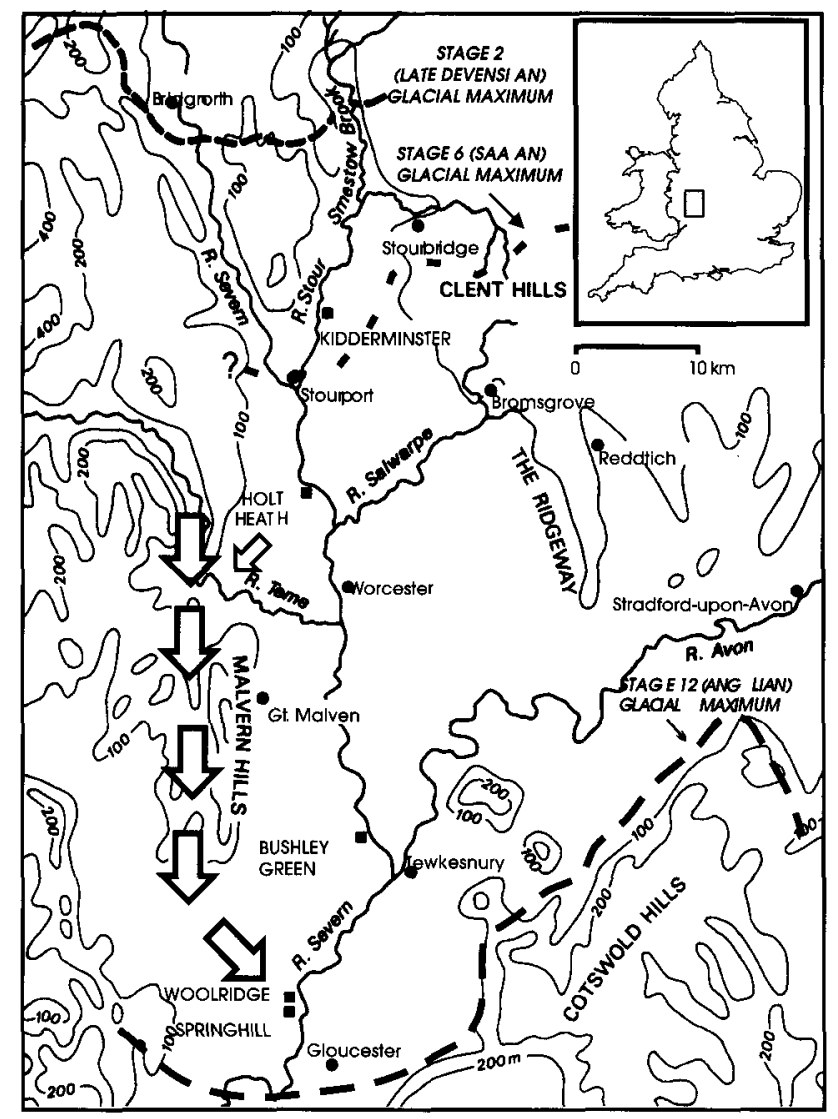

Fig. 1. The lower Severn valley. Bold arrows indicate the probable main Pre-Anglian drainage line (after Barclay et al., 1992).

\section{Previous Studies}

Research into the drainage development in this region has attracted the attention of some of the most influential geomorphologists of the past century (e.g. Davis, 1892; Buckman, 1899,1902; Wills, 1948; Linton, 1951). These early investigations were based solely on landform evidence, concentrating on the description of stream alignments and their relationship to underlying geological structures. This early work allowed long-term landscape evolution models to be suggested but subsequently many of these ideas have been modified or rejected in the light of more recent examination of the sedimentary record. These later studies elaborate a more complex development and demonstrate the power of relatively short-term events in modifying drainage patterns.

The earliest descriptions of the river terrace gravel deposits in the Severn valley are by Murchison (1836, 1839), Symonds (1861) and Maw (1864), who believed that the gravels were marine, a conclusion apparently confirmed by the presence of marine shells (Symonds, 1861). However, later investigations by Lucy (1872), mainly in the tributary Avon valley, ascribed many of these gravel deposits to a terrestrial origin. The acceptance of the 'glacial theory' in the latter half of the nineteenth century led to the recognition that large areas of the Severn basin had been glaciated (e.g. Harrison, 1898) introducing a new, complicating factor into the understanding of this sedimentary record. It was soon realized that the marine shells in the terrace gravels were introduced by glacial incursion into the basin and therefore did not reflect a marine depositional environment.

However, later in the nineteenth century advances in the understanding of river system behaviour demonstrated that large-scale landscape evolution could result solely from fluviatile action. This conclusion was reflected in the early twentieth century work of Gray $(1911,1912,1914,1919)$ who was not convinced by the wholesale application of a glacial origin to the deposits of the Severn basin, and maintained that many of the deposits could be explained by the fluvial redistribution of glacial sediments.

Further significant advances however did not arise until the deposits were mapped in detail by Wills (1924, 1937, 1938). He recognised a series of river terraces at progressively higher levels above the present river. Wills was able to demonstrate that the terrace deposits testify to a complex interaction of fluvial processes and repeated glacial encroachment into the basin. Significantly, he recognised that the terrace flight post-dated a major glaciation that covered almost the entire basin and that subsequent, less extensive glaciations, encroached into the lower basin influencing fluvial system behaviour. Perhaps most significantly he noticed that the present catchment area, which drains much of mid Wales, is a relatively recent phenomenon, being the product of Late Devensian (OIS 2) glacial diversion. Prior to the Late Devensian the Severn watershed did not extend much upstream of Bridgnorth (Fig. 1). Wills (1948) extended his work to include a comprehensive assessment of the development of the Severn valley over the whole Quaternary, including long-term tectonic factors.

Subsequent work on the Severn valley deposits (e.g. Hey, 1958; Maddy et al., 1995) has tended to build upon the work of Wills, providing progressively more detail and applying technological advances which in turn are allowing new questions to be asked. Of particular interest are questions which relate to the driving mechanisms of fluvial system behaviour in the lower Severn valley. Of interest in this paper is the question 'What drives river terrace development in the Lower Severn Valley?' In order to address this, it is first necessary to present the current state of knowledge with respect to the Severn sedimentary record. 


\section{Severn Valley stratigraphy}

During the past two decades river terrace deposits have been classified in the UK using formal lithostratigraphical nomenclature (e.g. Gibbard, 1985; Whiteman and Rose, 1992). The terrace deposits of the Severn were first formally defined by Maddy et al. (1995), although this system was later expanded (Bowen, 1999; Table 1). This lithostratigraphical framework has been tied to the global oxygen isotope stratigraphy (e.g. Shackleton et al., 1990) using both biostratigraphical and geochronological correlation (see below). This correlation allows an approximate chronology to be established for the sequence as a whole, which further allows some discussion of the timing and probable causes of major fluvial system adjustments.

Without doubt the most significant event recorded in the sedimentary record of the lower Severn valley is the extensive Middle Pleistocene glaciation (recognized by Wills) that deposited the widespread Wolston/Nurseries Formations (Table 1) and is believed to be time-equivalent to Oxygen Isotope Stage 12 (Anglian) (Bowen, 1999). Within the lower Severn valley the Anglian glaciation is represented by the Woolridge Member of the Wolston Formation. This member forms the Woolridge Terrace of Wills (1938) that can be traced on isolated hills above $80 \mathrm{~m}$ OD downstream of Tewkesbury (Hey, 1958). Typically this member is generally less than $2 \mathrm{~m}$ in thickness and consists of sandy clayey coarse gravels. At Woolridge this member lies directly on top of till correlated with the Thrussington Member of the Wolston Formation and thus these sediments are interpreted as outwash from the Anglian ice-sheet. The Woolridge
Member thus provides an important chronological marker within the lithostratigraphic sequence, time equivalent to OIS12. Pre-Anglian river Severn sediments form the Mathon Formation, while post-Anglian river Severn sediments comprise the Severn Valley Formation.

\section{Mathon Formation}

The Mathon Formation represents drainage along a north-south drainage line west of the Malvern Hill axis (Barclay et al., 1992: Fig. 1). This river system was considered by Barclay et al. (1992) to have existed immediately prior to the Anglian glaciation. During this time much of the lower Severn area drained via this route. No geochronology is available from this Formation although biostratigraphical correlation between organic beds within this sequence and organic channel fill sediments at Waverley Wood Farm has been suggested (Allan Brandon pers comm.). These latter sediments have been correlated with OIS 15 on the basis of their aminostratigraphy (Bowen et al., 1989) and to the late Cromerian complex using biostratigraphy (Shotton et al., 1993).

\section{Severn Valley Formation}

The post-Anglian river terrace sequence of the lower Severn valley is discussed in detail by Maddy et al. (1995), a summary of which is given below (see table $1)$.

\section{Spring Hill Member}

The Spring Hill Member of the Severn Valley Formation was first identified by Maddy et al. (1995) and

Table 1 Lithostratigraphic nomenclature for the lower Severn valley (after Bowen, 1999).

\begin{tabular}{|c|c|c|c|c|}
\hline OI Stage & $\begin{array}{l}\text { Formation } \\
\text { fluvial }\end{array}$ & Members & $\begin{array}{l}\text { Formation } \\
\text { glacial }\end{array}$ & Stage \\
\hline
\end{tabular}

\begin{tabular}{|c|c|c|c|c|}
\hline 2 & & Power House & & \\
\hline 2 & & Worcester & & \\
\hline $5 e-2$ & & Holt Heath & Stockport Late & Devensian \\
\hline 6 & $\begin{array}{l}\text { Severn } \\
\text { Valley }\end{array}$ & Kidderminster Station & Ridgacre & 'Saalian' \\
\hline $9-8$ & & Bushley Green & & \\
\hline $11-10$ & & Spring Hill & & \\
\hline 12 & & Woolridge & Wolston & Anglian \\
\hline pre 12 & Mathon & & & \\
\hline
\end{tabular}


can be mapped from just south of the present Stour / Severn confluence downstream to Gloucester, suggesting the basin drained an area roughly equivalent to the present lower Severn Valley. A maximum thickness of $7.2 \mathrm{~m}$ has been recorded but typically these sediments are no more than $2-3 \mathrm{~m}$ in thickness. This member was assigned to OIS 10 by Maddy et al. (1995) on the basis that it pre-dates the Bushley Green Member and succeeds the Woolridge Member of the Wolston Formation. However, no geochronological evidence is available directly from this member to securely attribute these sediments to this stage.

\section{Bushley Green Member}

The Bushley Green Member represents the sediments that comprise the Bushley Green terrace of Wills (1938) and can be mapped from Lower Broadheath to Apperley with an upper surface ca. $45 \mathrm{~m}$ above the present river. A thickness of $6.9 \mathrm{~m}$ has been recorded at the type locality but generally this member is less than $4 \mathrm{~m}$ in thickness. Amino acid ratios from Bushley Green suggest time equivalence of the basal temperate sediments with OIS 9 (Bowen et al., 1989), the overlying cold climate (indicated by the presence of cryogenic structures), high-energy river sediments being attributed to OIS 8 (Bridgland et al., 1986).

\section{Kidderminster Station Member}

The Kidderminster Station Member represents the sediments that comprise the Kidderminster terrace of Wills (1938) and can be traced along the whole length of the Lower Severn and up the Stour Valley beyond Stourbridge. This member is particularly well developed in the Stour Valley (Fig. 1) where it has been little affected by subsequent erosion with sequences up to $7.9 \mathrm{~m}$ in thickness. Downstream this member is believed to be generally much thinner. The sediments contain a suite of lithologies not seen before in the higher Severn Valley members. These include the Permian Clent Breccias which although local had become available for the first time. However, more exotic clasts include large Welsh volcanic boulders (Wills, 1938) that are similar to Welsh boulders associated with surface glacigenic sediments east of the Stour valley around Churchill. Rock exposure age estimates using ${ }^{36} \mathrm{Cl}$ methods from several of these boulders suggest time equivalence with OIS 6 (Maddy et al., 1995). Given that the Kidderminster Station Member is equivalent to the Cropthorne Member of the Avon Valley Formation that is known to be of OIS7-6 age (Maddy et al., 1991; De Roufignac et al., 1994) it is likely that the Kidderminster Station Member is closely associated with Stage 6 (Saalian) glaciation. Hence the new lithologies may be the re- sult of glacial erosion in the Clent Hills area (Fig. 1). No OIS 7 deposits have been identified within the main Severn Valley.

\section{Holt Heath Member}

The Holt Heath Member is the most easily mapped of the lower Severn terraces and comprises the sediments identified by Wills (1938) as the Main Terrace, which have recorded thickness up to $10 \mathrm{~m}$. This member can be mapped from Bridgnorth where it lays approximately $30 \mathrm{~m}$ above the present river to Gloucester where it descends beneath the modern floodplain. Last interglacial sediments (OIS 5e) may be present at the base of this member at Stourbridge (Boulton, 1917), although this faunal record of hippopotamus is of uncertain value given the likelihood of reworking. Younger sediments within this member include organic channel fill sediments attributable to the Upton Warren Interstadial Complex at Upton Warren (SO 935673) in the tributary Salwarpe valley (Fig. 1). Radiocarbon age estimate of 41, 500 \pm 1200 and $41,900 \pm 800$ B.P. suggest time equivalence with OIS 3 (Coope et al., 1961). However, amino acid ratios of $0.066 \pm 0.007$ may suggest these dates are underestimates (Bowen et al., 1989). The majority of the sediments within the main valley were deposited by outwash from the Devensian (OIS 2) ice sheet as they contain characteristic Lake District and Scottish erratics. Advance of the Late Devensian ice sheet into this area (Fig. 1) is believed to postdate 28ka (Morgan, 1973).

\section{Worcester Member}

The Worcester Member comprises the identified as the Worcester Terrace by Wills (1938). The upper terraced surface lies approximately $8 \mathrm{~m}$ below the Holt Heath Member and is traceable from Bewdley to Tewkesbury where it continues below the level of the current alluvium (Beckinsale \& Richardson, 1964). The deposits consist of sands and gravels that are often coarse. Although no direct geochronology is available, this member is thought to have been deposited after the Late Devensian reached its maximum extent at c.18 ka and given the age of the Power House Member (see below) it must pre-date $13 \mathrm{ka}$. The sediments are therefore most likely to result from highenergy flows during deglaciation (Dawson, 1989).

\section{Power House Member}

The Power House Member comprises the sediments identified as the Power House Terrace of Wills (1938), although several discontinuous terraces are most likely present. The sediments are up to $12 \mathrm{~m}$ in thickness and can be mapped from Bridgnorth to 
Worcester (Williams, 1968). Below Worcester the deposits are correlated with sediments beneath the modern alluvium (Beckinsale \& Richardson, 1964). Organic sediments at Stourport have been dated through radiocarbon age estimation to $12,570 \pm 220$ B.P. (Shotton \& Coope, 1983). Brown (1982) considered these sediments to be the post-glacial valley fill.

\section{River terrace development and incision history}

The answer to the question "what drives river terrace development in the lower Severn valley?' is not easily determined as numerous factors could play a significant role. Adjustments in river longitudinal profile, leading to floodplain abandonment and terrace formation, can occur in response to a variety of internal fluvial system dynamic changes and external stimuli occurring at different temporal and spatial scales. The terrace sequence described above results from basinwide fluvial incision events during the Middle - Late Pleistocene. Incision events resulting in terrace formation at this scale most probably reflect response to changes in external variables such as changing climates, base-level changes or tectonic adjustments. Unfortunately, during the Quaternary these variables would have driven fluvial activity collectively, making the identification of the relative importance of a single cause difficult. Furthermore, the picture may be made more complicated by the superimposition upon these basin-wide events of significant reach-scale incision resulting from localized catchment changes. Despite these problems some observations do allow plausible causes of incision to be evaluated.

\section{Base-level change}

A model of progressive sea-level lowering during the Quaternary, proposed by Fairbridge (1961), was an often-cited mechanism (e.g. Clayton, 1977) for the progressive incision of river valleys i.e. where a lowering of base level of a river is not balanced by lengthening of its course, incision will result in changes in profile immediately upstream. Such incision could, given enough time and a readily erodible substrate, be transmitted throughout the whole basin via knickpoint recession. Hence low sea levels, during cold stages, could have resulted in downstream incision with subsequent transmission of this incision upstream via knickpoint recession.

Little is known about the downstream extension of the Severn through the Bristol Channel and beyond during low sea level stands. However, it is likely that the river simply extended it course offshore, incising only in the very downstream reaches close to the con- tinental shelf-break hundreds of kilometres offshore. Schumm (1993) and Leopold and Bull (1979) have suggested that the effects of base-level change will tend not to be propagated far upstream, particularly in large rivers, which have more scope to accommodate adjustment via other channel variables. Thus sea-level controlled incision is an unlikely cause of the incision in the lower Severn valley.

\section{Climatic change}

Climate-driven changes have undoubtedly been important in governing aggradation-incision cycles (Bull, 1991; Bridgland, 1994; Bridgland \& Maddy, 1995; Maddy et al., 2000; Maddy et al., 2001). Climatic control exerts influence on the sediment/discharge ratio with incision promoted when low sediment availability is concurrent with high discharge and aggradation being promoted in times of high sediment supply. Leeder \& Stewart (1996) have suggested that incision may be initiated upstream, when increasing discharge outpaces increasing sediment availability. This can migrate downstream, a process they referred to as discharge-controlled incision or 'kinetic incision', thus providing a mechanism for the transmission of upstream initiated incision throughout the whole basin.

The conditions necessary for the initiation of incision might, for example, be anticipated at the beginning of warm events when hill-slope stabilization by vegetation reduces sediment supply. The occurrence of interglacial sediments at the base of river terrace sediment packages in the Severn e.g. Bushley Green (OIS 9) and Stourbridge (OIS 5e) tends to suggest that incision has indeed occurred immediately prior to the interglacial i.e. on the glacial-interglacial transition. Unfortunately the apparent lack of interglacial sediment preservation within the Spring Hill and Kidderminster Station Members prevents confirmation of this timing for the initiation of their precursor incision events. However, OIS 7 sediments are known from the base of a terrace in the Avon Valley equivalent to the Kidderminster terrace (Maddy et al., 1991). This timing of incision also occurs when global sea-levels are rising, providing further evidence for the relative unimportance of sea-level change as a driving mechanism. Although there is no direct evidence to support a climate-driven mechanism for the incision between the deposition of the Holt Heath and Worcester Members, climate change may in part drive the incision from the Worcester Member to the Power Station Member and subsequent incision to the base of the Holocene floodplain i.e. during the OIS 2-1 glacial-interglacial transition. 
Although climate control is therefore important in governing the likely timing of some incision events it cannot provide a mechanism which leads to longterm progressive valley incision. This problem is discussed in relation to terrace formation in the Thames valley (UK) by Maddy (1997) and Maddy et al. $(2000,2001)$. In these papers it is suggested that climate change governs the timing of aggradation-incision cycles, in synchrony in the Thames, as here in the Severn, with the Milankovitch glacial-interglacial cycles, but progressive valley incision and the consequent development of terrace staircases must require long-term tectonic uplift. These conclusions are supported by recent modelling exercises (e.g. Veldkamp \&Van Dijke, 2000).

\section{Crustal instability}

The concept of uplift control on valley incision has had a long history in the geomophological literature, embodied in the ideas of rejuvenation. More recent studies have demonstrated that valley incision can result from crustal uplift (e.g. Bull, 1991). Mechanisms for crustal uplift in Southern England were discussed by Maddy et al. (2000) who list a number of mechanisms including: direct plate-tectonic stress at, or near, plate margins; intraplate stress (e.g. Cloetingh et al., 1990) and large-scale glacioisostatic adjustment (e.g. Lambeck, 1993, 1995).

Using the stratigraphical information given above it is possible to reconstruct former floodplain levels for the period since the Anglian glaciation. Fig. 2 shows interpolated longitudinal profiles of the river terraces mapped in the lower Severn valley based upon the height of the terrace surfaces at five localities (Table 2 ). This diagram illustrates some interesting patterns that require consideration: a) The OIS12 (late Anglian) Woolridge Member is incised by c. $30 \mathrm{~m}$ prior to deposition of the OIS1110 Spring Hill Member. As this area was completely covered by Anglian ice it is reasonable to anticipate that the region was glacio-isostatically depressed until deglaciation and hence this unusually high amount of incision may be a response to glacio-isostatic rebound.

b) The incision from the Holt Heath - Worcester Power House Members is associated with deglaciation at the end of OIS2 (Devensian) and thus may also be associated with glacio-isostatic compensation, with greater amounts of localized incision, up to c. $30 \mathrm{~m}$, closer to the ice front. The pause in incision during Devensian deglaciation, indicated by the deposition of the Worcester Member, may reflect a short-lived re-advance of the Devensian icesheet, or more likely a catastrophic phase of icesheet down-draw resulting in substantial outwash deposition.

In both cases $(\mathrm{a}, \mathrm{b})$ therefore the incision levels associated with deglaciation are of the same order of magnitude and are similar to levels of incision in front of the Anglian ice-sheet in the Thames valley where Maddy \& Bridgland (2000) have argued for a glacio-isostatic component.

c) There is an downstream decrease in terrace gradient of the Holt Heath Member, perhaps reflecting increased warping of the terrace towards the icesheet margin, perhaps reflecting differential rebound. A similar picture emerges with the Kidderminster Station Member perhaps suggesting similar warping of the terrace profile during late OIS6 (Saalian), although evidence from this event is much more ambiguous.

Using the altitude of the base of each terrace (Table 2) for the five localities used above, time-aver-

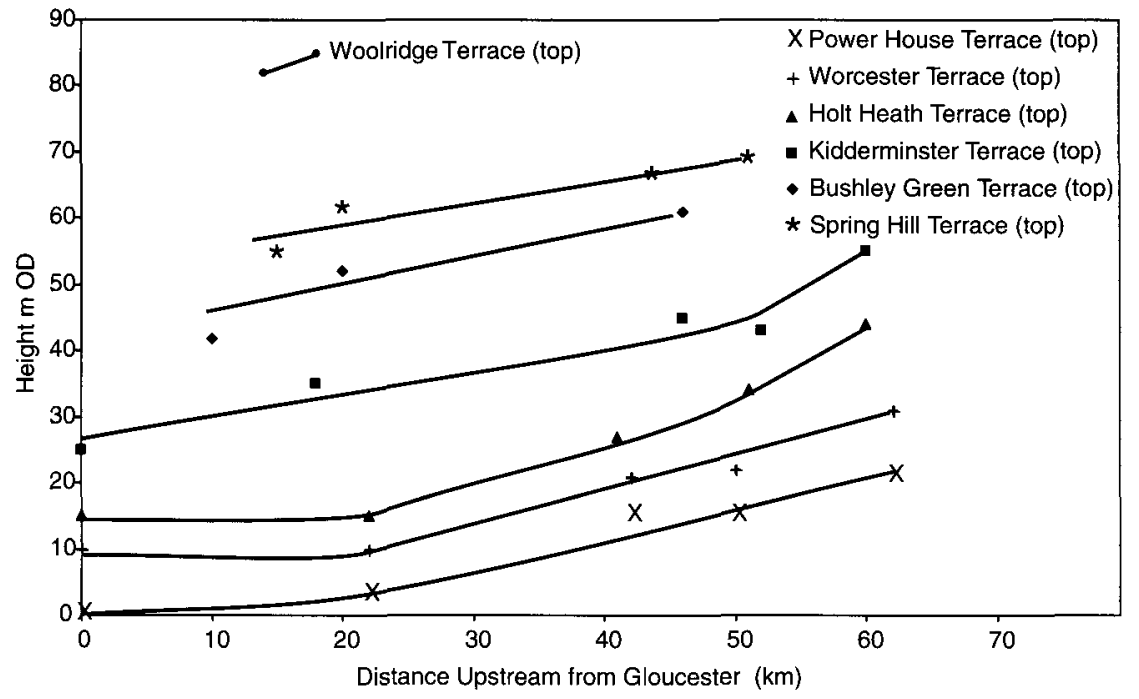

Fig. 2. Interpolated terrace surface longitudinal profiles based upon heights shown in Table 2. 
Table 2. Age-altitude data for the members of the Severn Valley Formation. Numbers in italics are estimates based upon observed thicknesses close by.

\begin{tabular}{|c|c|c|c|c|c|c|c|c|}
\hline & $\begin{array}{l}\text { Top age } \\
\mathrm{ka}\end{array}$ & $\begin{array}{l}\text { Top } \\
\mathrm{m} \mathrm{OD}\end{array}$ & $\begin{array}{l}\text { Bottom age } \\
\text { ka }\end{array}$ & $\begin{array}{l}\text { Bottom } \\
\text { m OD }\end{array}$ & Location & Grid Ref & $\delta 1$ & Reference \\
\hline \multicolumn{9}{|l|}{ Gloucester } \\
\hline Woolridge & 430 & 82 & & 81 & Woolridge & SO806237 & 14 & Maddy, 1989 \\
\hline Spring Hill & 330 & 55 & 425 & 52 & Spring Hill & SO808232 & 15 & Lucy, 1872 \\
\hline Bushley Green & 250 & 42 & 325 & 40 & Apperley & SO863282 & 10 & Maddy, 1989 \\
\hline Kidderminster & 140 & 25 & 225 & 21 & Maisemore & SO810214 & 0 & Worssam et al., 1989 \\
\hline Main & 18 & 15 & 125 & 11 & Maisemore & SO814210 & 0 & Worssam et al., 1989 \\
\hline Worcester & 15 & 10 & 17 & 0 & Maisemore & SO816210 & 0 & $\begin{array}{l}\text { Worssam et al., 1989, } \\
\text { Beckinsale \& Richardson, } 1964\end{array}$ \\
\hline Power House & 11 & 0 & 13 & -9 & Maisemore & SO817212 & 0 & Worssam et al., 1989 \\
\hline \multicolumn{9}{|l|}{ Tewkesbury } \\
\hline Woolridge & 430 & 85 & & 83 & Sarn Hill Wood & SO859343 & 18 & Maddy, 1989 \\
\hline Spring Hill & 330 & 62 & 425 & 59 & Windmill Tump & SO865351 & 20 & Maddy, 1989 \\
\hline Bushley Green & 250 & 52 & 325 & 45 & Bushley Green & SO862351 & 20 & Maddy, 1989 \\
\hline Kidderminster & 140 & 35 & 225 & 31 & The Mythe & SO890340 & 18 & Worssam et al., 1989 \\
\hline Main & 18 & 15 & 125 & 12 & Ripple & SO876373 & 22 & Maddy, 1989 \\
\hline Worcester & 15 & 10 & 17 & 3 & Queenhill & SO868369 & 22 & $\begin{array}{l}\text { Worssam et al., } 1989, \\
\text { Beckinsale \& Richardson, } 1964\end{array}$ \\
\hline Power House & 11 & 3 & 13 & 0 & Queenhill & SO868369 & 22 & Beckinsale \& Richardson, 1964 \\
\hline \multicolumn{9}{|l|}{ Worcester } \\
\hline Spring Hill & 330 & 67 & 425 & 65 & Atchen Hill & SO810555 & 44 & Moorlock et al., 1985 \\
\hline Bushley Green & 250 & 61 & 325 & 58 & Lower Broadheath & SO 809573 & 46 & Moorlock et al., 1985 \\
\hline Kidderminster & 140 & 45 & 225 & 41 & Hallow & SO828580 & 46 & Moorlock et al., 1985 \\
\hline Main & 18 & 27 & 125 & 24 & Worcester & SO835535 & 41 & Wills, 1928 \\
\hline Worcester & 15 & 21 & 17 & 16 & Worcester & SO848540 & 42 & Beckinsale \& Richardson, 1964 \\
\hline Power House & 11 & 15 & 13 & 8 & Worcester & SO 848540 & 42 & Beckinsale \& Richardson, 1964 \\
\hline \multicolumn{9}{|l|}{ Holt Heath } \\
\hline $\begin{array}{l}\text { Spring Hill } \\
\text { Bushley Green }\end{array}$ & 330 & 69 & 425 & 67 & Old Hill & SO814616 & 51 & Moorlock et al., 1985 \\
\hline Kidderminster & 140 & 43 & 225 & 40 & Holt Heath & SO818628 & 52 & Maddy, 1989 \\
\hline Main & 18 & 34 & 125 & 25 & Holt Heath & SO827627 & 51 & Dawson \& Bryant, 1987 \\
\hline Worcester & 15 & 22 & 17 & 12 & Grimley & SO835608 & 50 & Dawson, 1989 \\
\hline Power House & 11 & 15 & 13 & 11 & Grimley & SO838609 & 50 & Beckinsale \& Richardson, 1964 \\
\hline \multicolumn{9}{|l|}{ Stourport } \\
\hline Kidderminster & 140 & 55 & 225 & 51 & $\begin{array}{l}\text { Hartlebury } \\
\text { Common }\end{array}$ & $\mathrm{SO} 825713$ & 60 & Maddy, 1989 \\
\hline Main & 18 & 44 & 125 & 40 & Stourport & $\mathrm{SO} 798717$ & 60 & Dawson, 1988; Goodwin, 1999 \\
\hline Worcester & 15 & 31 & 17 & 21 & Wilden & $\mathrm{SO} 825729$ & 62 & Brown, 1983 \\
\hline Power House & 11 & 21 & 13 & 18 & Wilden & SO824730 & 62 & $\begin{array}{l}\text { Shotton \& Coope, 1983; } \\
\text { Brown, } 1983\end{array}$ \\
\hline
\end{tabular}

$\delta l$ distance upstream $(\mathrm{km})$ from Gloucester

aged incision rates for the whole post-Anglian period can be reconstructed (shown in Fig. 3 a, b). These data show remarkable consistency suggesting incision during the past $400 \mathrm{ka}$ at a time-averaged rate of $\mathrm{c}$. $0.15 \mathrm{~m} \mathrm{ka}^{-1}$. This observation is remarkable given the repeated glaciation of the basin; the glacio-isostatic effects noted above appear therefore to have had only short-term effect on the overall valley incision rate. This latter observation also perhaps suggests that complete glacio-isostatic compensation is achieved with no net upward or downward crustal movement, suggesting therefore that glacial erosion was less than that required to necessitate isostatic compensation.

The calculated incision rate of $0.15 \mathrm{~m} \mathrm{ka}^{-1}$ compares with rates of $0.07 \mathrm{~m} \mathrm{ka}^{-1}$ calculated from the terrace record of the Upper Thames (Maddy, 1997) and rates of c. $0.10 \mathrm{~m} \mathrm{ka}^{-1}$ in the Lower Thames valley (Maddy et al., 2000). This higher incision rate is consistent with the west-east tilting of the Jurassic/Cretaceous strata to the east of the Severn valley, suggest- 

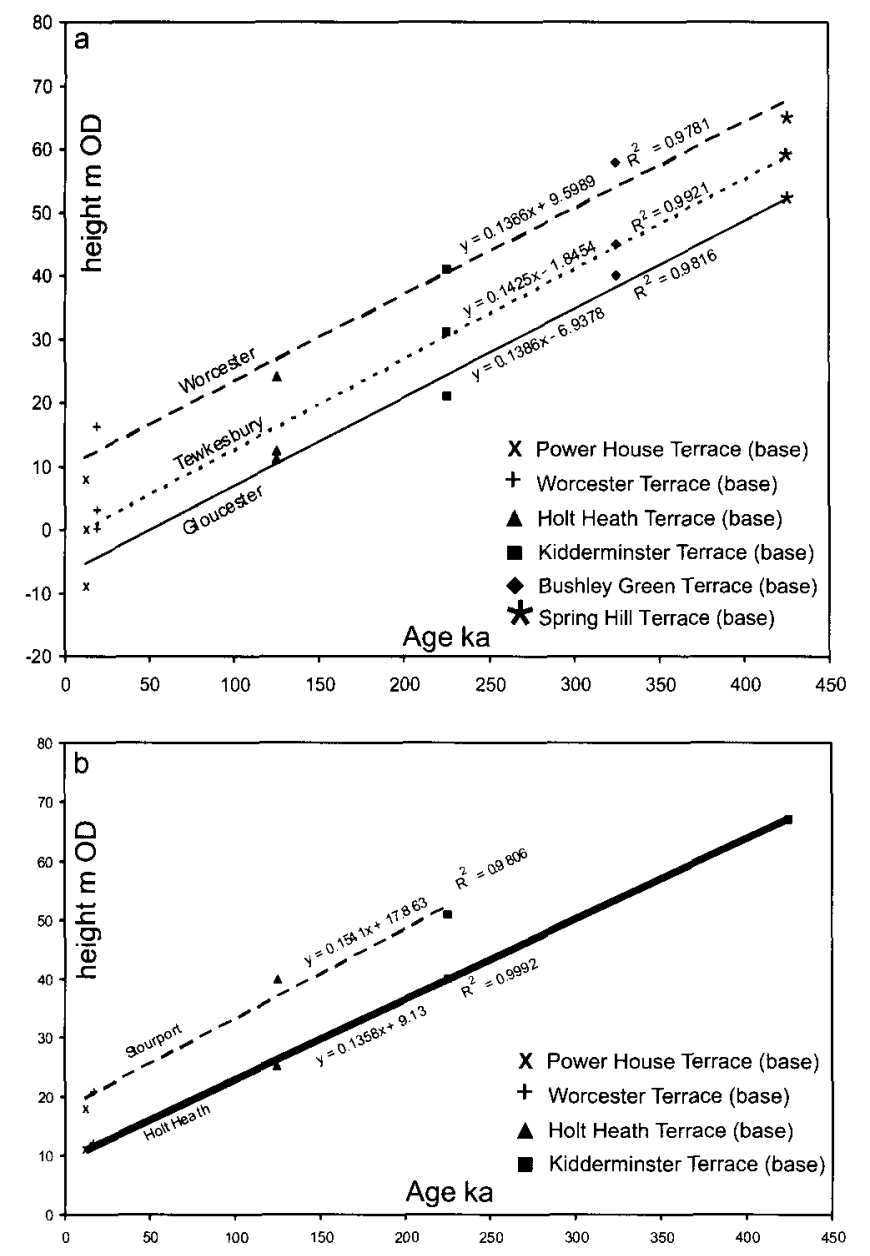

Fig. 3. Calculated incision rates in the lower Severn valley based upon the base of the terrace aggradations at a: Gloucester, Tewksbury and Worcester; b: Holt Heath and Stourport. All localities shown on Fig. 1. Each line represents a linear regression $(Y=\alpha+$ $\beta \mathrm{X}$ ) at a specific location in the lower Severn Valley ranging from Stourport (upstream) to Gloucester (downstream). In each case the explanatory variable $(Y)$ represents terrace base altitude and the independent variable $(\mathrm{X})$ represents estimated age (based on Table 2). Thus the slope parameter $\beta$ is an estimate of the time-averaged incision rate $\left(\mathrm{m} \mathrm{ka}^{-1}\right)$.

ing this pattern may be the continued response to a long-term crustal adjustment, perhaps even to doming (Cope, 1994). However, Maddy (1997) and Westaway et al. (2002) suggest that increased uplift rates begin immediately prior to the onset of lowland glaciation c. $2.6 \mathrm{Ma}$ and argue that this uplift is largely therefore a Quaternary phenomenon. This conclusion is based not only on the identification of the onset of valley incision in the UK but also much further afield in the Netherlands (Van den Berg, 1996; Westaway (2001) and France (Antoine, 1994).

Westaway (2001) and Westaway et al. (2002) present a model for uplift driven by flow in the lower continental crust in response to the repeated pressure/thermal gradient changes induced by the loading/unloading cycles of sea-level change on the conti- nental shelf and ice-sheet waxing and waning on the continents. An alternative mechanism involving lithospheric flexure in response to erosion of the Late Triassic and Early Jurassic clays and marls from areas surrounding the Severn valley has been suggested by Watts et al. (2000). They argue that this erosion has taken place during the post-Anglian period suggesting connection with a depocentre in the Celtic deep. Unfortunately Watts et al. (2000) failed to consider the published information on the sedimentary record of the Severn and Avon (Maddy et al., 1991; Maddy, 1999), which does not support the erosion rates they suggest in the post-Anglian period. However, longerterm erosion (i.e. the whole Pleistocene) of this area may have been a contributory factor in driving enhanced uplift and may help explain the higher rates of incision seen in this area. A detailed consideration of the mechanisms driving uplift in this area will be the subject of a later paper.

\section{Conclusions}

The Pleistocene development of the lower Severn valley is typical of other rivers in Southern England in that the long-term incision appears to be driven by crustal uplift. Similarly, the stratigraphy of the terraced sediment bodies appears to support the timing of terrace aggradation and incision being principally driven by sediment/discharge changes consequent upon climate change, a phenomenon already noted from the Thames valley (Bridgland, 1994; Maddy et al., 2001). The terrace staircase therefore appears to directly reflect the Milankovitch-driven 100 ka climate cycles, with incision concentrated during the coldwarm transitions (although not exclusively limited to these periods) and aggradation during warm-cold climate transitions and to a more limited extent within the cold climate episodes themselves. Base level controls on this system are believed to be insignificant.

Although the overall level of valley incision is governed by regional uplift, complex terrace sequences can develop in response to localized changes. In the case of the Severn, a complex Late Devensian deglacial history has resulted in multiple terraces forming during a phase of glacio-isostatic rebound. The greatest incision rates experienced during this deglaciation reflect adjustments in river response to this rebound together with accommodation of the uplift experienced during the cold stage.

\section{Acknowledgements}

This paper represents a contribution to IGCP449 (Global correlation of Late Cenozoic fluvial de- 
posits). Thanks go also to the referees for critical and helpful comments on an earlier version of this paper.

\section{References}

Antoine, P., 1994. The Somme valley terrace system (northern France): a model of river response to Quaternary climatic variations since $800,000 \mathrm{bp}$. Terra Nova 6: 453-464.

Ambrose, K., Moorlock, B.S.P. \& Cannell, B., 1985. The geology of sheet SO84. Keyworth: British Geological Survey.

Barclay, W.J., Brandon, A., Ellison, R.A. \& Moorlock, B.S.P., 1992. A Middle Pleistocene palaeovalley-fill west of the Malvern Hills. Journal of the Geological Society of London 149: 75-92.

Beckensale, R.P. \& Richardson, L., 1964. Recent findings on the physical development of the lower Severn valley. Geographical Journal 130: 87-105.

Bowen, D.Q. (ed.), 1999. A correlation of Quaternary deposits in the British Isles. Geological Society of London Special Report 23.

Bowen, D.Q., Hughes, S., Sykes, G.A. \& Miller, G.H., 1989. Landsea correlations in the Pleistocene based on isoleucine epimerization in non-marine molluscs. Nature 340:49-51.

Boulton, W.S., 1917. Mammalian remains in the glacial gravels at Stourbridge. Proceedings of the Birmingham Natural History and Philosophical Society 14:107-112.

Bridgland, D.R., 1994. Quaternary of the Thames. Geological Conservation Review Series No.7. Chapman and Hall (London): 441pp.

Bridgland, D.R., 2000. River terrace systems in north-west Europe: an archive of environmental change, uplift and early human occupation. Quaternary Science Reviews 19: 1293-1303.

Bridgland, D.R. \& Maddy, D., 1995. River terrace deposits: long Quaternary terrestrial sequences. Abstracts, XIV INQUA Congress, Berlin: 37.

Bridgland, D.R., Keen, D.H. \& Maddy, D., 1986. A reinvestigation of the Bushley Green Terrace typesite, Hereford and Worcester. Quaternary Newsletter 50: 1-6.

Brown, A.G., 1982. Late Quaternary Palaeohydrology, Palaeoecology and Floodplain development of the Lower River Severn. Unpublished PhD thesis, University of Southampton.

Brown, A.G., 1983. Wilden. In: Brown, A.G. (ed.): The Severn 1983: Excursion Guide. INQUA Eurosiberian subcommission for the study of the Holocene and IGCP Project 158 Palaeohydrology of the Temperate Zone in the last 15,000 years, (Shrewsbury): 28-30.

Buckman, S.S., 1899. The development of rivers, and particularly the genesis of the Severn. Natural Science 14:273-89.

Buckman, S.S., 1902. River Development. Geological Magazine: 367-375.

Bull, W. B., 1991. Geomorphic responses to climate change. Oxford University Press (Oxford): 329pp.

Clayton, K.M., 1977. River Terraces. In: Shotton, F.W. (ed.): British Quaternary Studies, Recent Advances. Oxford University Press (Oxford): 153-168.

Cloetingh, S., Gradstein, F.M., Kooi, h., Grant, A. C. \& Kaminski, M., 1990. Plate reorganisation: a cause of rapid late Neogene subsidence and sedimentation around the North Atlantic. Journal of the Geological Society of London 147: 495-506.

Coope, G.R., Shotton, F.W. \& Strachan, I., 1961. A Late Pleistocene fauna and flora from Upton Warren, Worcestershire. Philosophical Transactions of the Royal Society B244: 379-421.

Cope, J.C.W., 1994. A latest Cretaceous hotspot and the southeasterly tilt of Britain. Journal of the Geological Society of London 151: $905-908$
Davis, W.M., 1895. The development of certain English rivers. Geographical Journal 5: 127-146.

Dawson, M.R., 1988. Diamict deposits of the pre-Late Devensian Glacial age underlying the Severn Main Terrace at Stourport, Worcestershire: their origins and stratigraphic implications. Proceedings of the Geologists' Association 99: 125-132.

Dawson, M.R., 1989. Chelmarsh. In: Keen, D.H. (ed.): The Pleistocene of the West Midlands: Field Guide. Quaternary Research Association (Cambridge): 80-85.

Dawson, M.R. \& Bryant, I.D., 1987. Three-dimensional facies geometry in Pleistocene outwash sediments, Worcester, U.K. In: Ethridge, F.G. (ed.): Recent developments in fluvial sedimentology. Society of Economic Palcontologists and Mineralogists Special Publication 39: 191-196.

De Rouffignac, C., Bowen, D.Q., Coope, G.R., Keen, D.H., Lister, A.M., Maddy, D., Robinson, E., Sykes, G.A. \& Walker, M.J.C., 1994. Late Middle Pleistocene deposits at Upper Strensham, Worcestershire, England. Journal of Quaternary Science 10: 1531 .

Ellison, R.A., Moorlock, B.S.P., Worssam, B.C., Wyatt, R.J. \& Baron, A.J.M., 1988. Tewkesbury 1:50,000 Solid and Drift Sheet 216. Keyworth. British Geological Survey.

Fairbridge, R.W., 1961. Eustatic changes in sea-level. Physics and Chemistry of the Earth 4: 99-185.

Gibbard, P.L., 1985. The Pleistocene history of the Middle Thames Valley. Cambridge University Press (Cambridge): 155pp.

Goodwin, M.D., 1999. Evidence for Late Middle Pleistocene glaciation in the British Isles. Unpublished PhD Thesis. Cheltenham and Gloucester College of Higher Education.

Gray, J.W., 1911. North and Mid Cotteswolds, and the Vale of Moreton during the Glacial Epoch. Proceedings of the Cotteswold Naturalists Field Club 17: 257-274.

Gray, J.W., 1912. The Lower Severn plain during the Glacial Epoch. Proceedings of the Cotteswold Naturalists Field Club 17: 365-380.

Gray, J.W., 1914. The drift deposits of the Malverns and their supposed glacial origin. Proceedings of the Birmingham Natural History and Philosophical Society 13:1-18.

Gray, J.W., 1919. Notes on the Cotteswold-Malvern region during the Quaternary Period. Proceedings of the Cotteswold Naturalists Field Club 20: 99-141.

Harrison, W.J., 1898. The ancient glaciers of the Midland counties of England. Proceedings of the Geologists' Association 15: 400408

Hey, R.W., 1958. High-level gravels in and near the Lower Severn Valley. Geological Magazine 95: 161-168.

Lambeck, K., 1993. Glacial rebound of the British Isles I: Preliminary model results. Geophysical Journal International 115: 941959.

Lambeck, K., 1995. Late Devensian and Holocene shorelines of the British Isles and North Sea from models of glacio-hydro-isostatic rebound. Journal of the Geological Society of London 152: 437-448.

Leopold L.B. \& Bull, W.B., 1979. Base level, aggradation and grade. Proceedings of the American Philosophical Society 123: 168-202.

Leeder, M.R. \& Stewart, M.D., 1996. Fluvial incision and sequence stratigraphy: alluvial responses to relative sea-level fall and their detection in the geological record. In: Hesselbo, S. P. \& Parkinson, D.N. (eds): Sequence stratigraphy in British Geology. Geological Society Special Publication 103: 25-39.

Linton, D.L., 1951. The Midlands Drainage. The Advancement of Science 7: 449-456.

Lucy, W.C., 1872. The gravels of the Severn, Avon and Evenlode, and their extension over the Cotteswold Hills. Proceedings of the 
Cotteswold Naturalists Field Club 5: 71-125.

Maddy, D., 1989. The Middle Pleistocene development of the rivers Severn and Avon. Unpublished $\mathrm{PhD}$ thesis, University of London.

Maddy, D., 1997. Uplift Driven Valley Incision and River Terrace Formation in Southern England. Journal of Quaternary Science 12: $539-545$.

Maddy, D., 1999. Reconstructing the Baginton River Basin and its implications for the early development of the River Thames drainage system. In: Andrews, P. \& Banham, P. (eds): Late Cenozoic Environments and Homonid Evolution: a tribute to Bill Bishop. Geological Society (London): 169-182.

Maddy, D., Keen, D.H., Bridgland, D.R. \& Green, C.P., 1991. A revised model for the Pleistocene development of the River Avon, Warwickshire. Journal of the Geological Society of London 148: 473-484.

Maddy, D., Green, C.P., Lewis, S.G. \& Bowen, D.Q., 1995. Pleistocene Geology of the Lower Severn Valley, UK. Quaternary Science Reviews 14: 209-222.

Maddy, D. \& Bridgland, D.R., 2000. Accelerated uplift resulting from Anglian glacioisostatic rebound in the Middle Thames valley, UK? : Evidence from the river terrace record. Quaternary Science Reviews 19: 1581-1588.

Maddy, D., Bridgland, D.R. \& Green, C.P., 2000. Crustal uplift in southern England: Evidence from the river terrace records. Geomorphology 33: 167-181.

Maddy, D., Bridgland, D.R. \& Westaway, R., 2001. Uplift-driven valley incision and climate-controlled river terrace development in the Thames Valley, UK. Quaternary International 79: 23-36.

Maw, G., 1864. On the drifts of the Severn in the neighbourhood of Colebrook Dale and Bridgnorth. Quarterly Journal of the Geological Society of London 20: 130.

Moorlock, B.S.P., Barron, A.J.M., Ambrose, K. \& Cannell, B., 1985. Geology of sheet SO85. Keyworth: British Geological Survey.

Morgan, A.V., 1973. The Pleistocene geology of the area north and west of Wolverhampton. Philosophical Transactions of the Royal Society of London B265: 233-297.

Murchison, R.I., 1836. Gravel and Alluvia in Worcestershire and Gloucestershire. Proceedings of the Geological Society 2: 230236.

Murchison, R.I., 1839. Silurian System. John Murray (London).

Penck, A. \& Brückner, E., 1909. Die Alpen im Eiszeitalter. Tauchnitz (Leipzig).

Schumm, S.A., 1993. River response to baselevel change: implications for sequence stratigraphy. Journal of Geology 101: 279-294.

Shackleton, N.J., Berger, A. \& Peltier, W.R., 1990. An Alternative Astronomical Calibration of the Lower Pleistocene Timescale Based on ODP Site 677 . Transactions of the Royal Society of Edinburgh 81:252-261.
Shotton, F.W. \& Coope,G.R., 1983. Exposures in the Power House Terrace of the River Stour, Wilden, Worcestershire, England. Proceedings of the Geologists' Association 94: 33-44.

Shotton, F.W., Keen, D.H., Coope, G.R., Currant, A.P., Gibbard, P.L., Aalto, M., Peglar, S.M. \& Robinson, J.E., 1993. The Middle Pleistocene deposits at Waverley Wood Pit, Warwickshire, England. Journal of Quaternary Science 8: 293-325.

Symonds, W.S., 1861. On the drifts of the Severn, Avon, Wye \& Usk. Proceedings of the Cotteswold Naturalists Field Club 3: 31-39.

Van den Berg, M.W., 1996. Fluvial sequences of the Maas: a 10Ma record of neotectonics and climate change at various time-scales. PhD Thesis, University of Wageningen.

Veldkamp, A. \& Van Dijke, J.J., 2000. Simulating internal and external controls on fluvial terrace stratigraphy: a qualitative comparison with the Maas record. Geomorphology 33: 225-236.

Watts, A.B., Mckerrow, W.S. \& Fielding, E., 2000. Lithospheric flexure, uplift, and landscape evolution in south-central England. Journal of the Geological Society of London 157: 1169-1177.

Westaway, R., 2001. Flow in the lower continental crust as a mechanism for the Quaternary uplift of the Rhenish Massif, northwest Europe. In: Maddy, D., Macklin, M. \& Woodward, J. (eds): River Basin Sediment Systems: Archives of Environmental Change. Balkema (Rotterdam): 87-168.

Westaway, R., Maddy, D. \& Bridgland, D.R., 2002. Flow in the lower continental crust as a mechanism for the Quaternary uplift of southeast England. Quaternary Science Reviews 21: 559-603.

Whiteman, C.A. \& Rose, J., 1992. Thames river sediments of the British Early and Middle Pleistocene. Quaternary Science Reviews 11:363-375.

Williams, G.J., 1968. The buried channel and superficial deposits of the lower Usk and their correlation with similar features in the lower Severn. Proceedings of the Geologists' Association 79: 325-348.

Wills, L.J., 1924. The development of the Severn Valley in the neighbourhood of Iron-Bridge and Bridgnorth. Quarterly Journal of the Geological Society of London 80: 274-314.

Wills, L.J., 1937. The Pleistocene History of the West Midlands. British Association for the Advancement of Science Presidential Address to Section C (Geology). British Association (London).

Wills, L.J., 1938. The Pleistocene development of the Severn from Bridgnorth to the sea. Quarterly Journal of the Geological Society of London 94: 161-242.

Wills, L.J., 1948. The palaeogeography of the Midlands. Hodder and Stoughton (Liverpool).

Worssam, B.C., Ellison, R.A. \& Moorlock, B.S.P., 1989. Geology of the country around Tewkesbury. Memoir of the British Geological Survey, Sheet 216 (England and Wales). HMSO (London). 